\title{
Religious symbol on determining the beginning and end of Ramadan in Indonesia
}

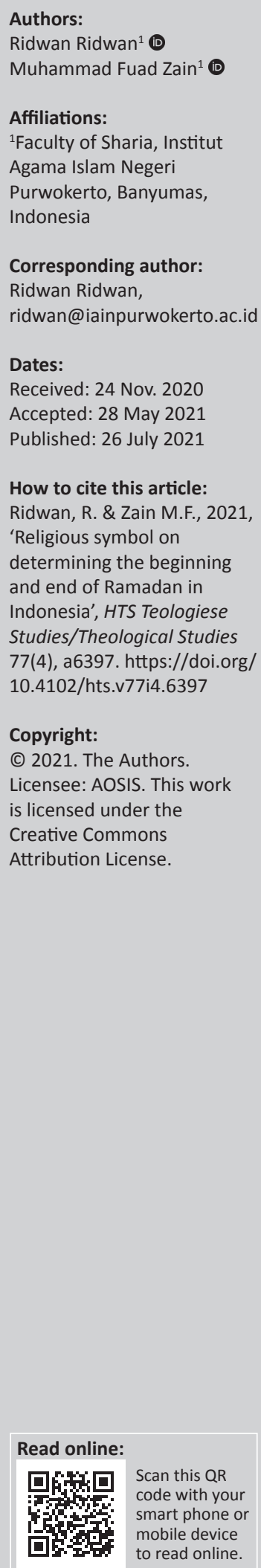

The fasting and Eid al-Fitr celebration has a strong public dimension for their traditional characteristics in Islamic communal celebrations. This study used field research from interviews with the two largest mass organisations in Indonesia, Nahdlatul Ulama (NU) and Muhammadiyah, and the statements of mass media. This research shows that contestation of religious symbols is not something that needs to be debated but it should broaden the understanding of the differences that must be respected in order to build brotherhood not, division. Contestation of religious symbols between the hisab [astronomical calculations] and the ru'yat [sighting a new crescent moon] is a competition between religious organisations, to strengthen their position, social legitimacy and religious authority in the public sphere. The government has to take the initiative to compromise the policy between the two Islamic organisations to reach a methodological agreement in order to minimise social tensions.

Contribution: This article proposed that understanding the ru'yat and hisab as a symbol of contestation becomes an attribute of religious organisations and part of organisational behaviour and culture.

Keywords: contestation; religious symbols; hisab; ru'yat; public sphere.

\section{Introduction}

The actual classical problem in Indonesia is the debate over determining the beginning of Ramadan and Shawwal. According to Djamaluddin, the difference in determining the days is not a serious problem, it frequently causes distress amongst Muslims that needs an immediate address to prevent a wide-scale social break up in the community (Djamaluddin 2011:10).

Every Ramadan, Indonesian Muslims are anxious whether the beginnings of the fasting month and Eid al-Fitr are on the same date for everyone (Suhanah 2012). Even though Islamic holidays are marked on the calendar, Muslims still wait for Ramadan's announcement every year. In Islamic law, worship should be performed punctually, amongst the requirements of worship is that it should be performed at the scheduled time.

The decision regarding the beginning of fasting and the celebration of Eid al-Fitr is basically a private religious affair. However, when the decision is taken by religious organisations and published widely (Prasetyo 2012b), it becomes a symbolic contestation as an explicit assertion of in-group or out-group (Susanto 1985:103-104). Fasting and Eid al-Fitr become the demonstration arena of groups existence wrapped in religious frames. The decision has shifted the paradigm of fasting and Eid al-Fitr from private to public dimension.

The paradigmatic shifts of fasting and Eid al-Fitr from private to public sector are because Islamic holidays come together with various government policies, namely the disbursement of Islamic holiday allowances, the increase in public transportation fare and the annual paid leaves arrangement. The government through the Ministry of Religious Affairs of the Republic of Indonesia takes the role by holding isbat (confirmation with argument and evidence) meeting, which is led by the minister and attended by the leaders of religious organisations and the Indonesian Council of Ulema, to decide the beginning and end of Ramadan to give legal certainty to the public. The method of hisab-ru'yat is used to make the decision.

The legal-religious arguments on the ru'yat and the hisab are the main reason for the differences to emerge. Behind the normative legal debates, there is another indistinct but legible reality, namely the contestation of religious symbols and identities built by the confronting parties to gain recognition 
from the public by presenting theological-normative arguments and authoritative religious texts (Hosen 2012).

Religion is the source of morality and worldview that arouses commitment and loyalty towards the ideology expressed in various symbols. Religious identity is seen as an essential factor in determining its adherents for having differences from others (Oppong 2013:6). The use of ru'yat and hisab methods in determining the beginning and end of Ramadan is a form of religious identity of Islamic social organisations as a characteristic to distinguish it from other religious organisations.

In Indonesia's constellation of religious symbols and discourse dominance, the Nahdlatul Ulama (NU) and Muhammadiyah have always been involved in a suspenseful relation whirl. Although the differences between the two are still in the branch domains of the religious doctrine, not the core domain, the discourse and religious symbols rivalry between them significantly influence the emergence of social disharmony amongst the Indonesian Muslim community. One of the latent religious identity contestation rooms is the decision of when to start and end Ramadan fasting (Azhari 2006).

Contestation is defined as a rivalry involving at least two or more parties on one problem for existence regardless of the inadequate or limited subjects or materials. Hubermas stated that contestation always occurs in public sphere, many parties fight for the territory to dominate and capture other parties, even though public and private spaces are very difficult entities to separate (Qodir 2015)

Some researches that have been carried out by scholars related to the differences in determining the beginning and end of Ramadan are mostly focussed on the debates of the legal aspects, which are normative and juridical, there are not many studies touching the dimensions of religious symbols fight to strengthen religious identity (Wahab 2011) amongst religious organisations to define their existence in public sphere (Hardiman 2014). The public sphere is not merely a physical place but also discourses or communication of public who produce spaces amongst them. In Indonesia, if the fight for religious identity is defined as the fight amongst Islamic religious organisations, then what actually happens between NU and Muhammadiyah is the fight for religious identity to confirm their identity in public space.

This article seeks to elaborate and analyse the reality of the differences in the determination of Ramadan's beginning and end between NU and Muhammadiyah in Indonesia by capturing the symbolic messages behind the use of religious symbols namely ru'yat and hisab in seizing social influence in public sphere. Using the Hubermas theory of public sphere, this article also analyses the political affiliation of social organisations with the state political authority.

\section{Literature review}

One of the roles of religion is to create a socio-religious identity to construct social solidarity and to instill unity in the religious group (Peek et al. 2005). Religious dimension relies on three aspects such as the context of ideology, social and spiritual to construct religious symbols (Coşgel 2004). Religion is an important aspect of understanding the meaning and identity of life. Similarly, ethnicity provides significant background for the construction of identity, meaning and community (Kim 2011).

Greetz, in Walter H. Capps, defines religion as a system of symbols to establish power, penetrate the mood and motivate people. Religion is also a system of symbols to strengthen the mood and motivation (Capps 1995:181). Symbolic anthropologists view humans as carriers of the products of a system of signs and symbols to be used as a means of communication (Jubba et al. 2020).

Malinowski points out that culture is the knowledge that is gained and used by someone to interpret experiences and thus establish social behaviours (Malinowski 1922:25). In contrast to Malinowski, Harris in 'The Rise of Anthropological Theory' views culture as something that emerges from the pattern of people's behaviour such as lifestyle and custom. The various religious symbols are influenced by social perceptions constructed by local cultural values (Harris 1968:16).

An interpretive approach is used to examine the contestation of religious symbols of Muhammadiyah and NU in Indonesia. The purpose is to comprehend the existence of religious practices in society as rituals and the meaning behind them discerned from the religious expression of Muhammadiyah and NU, explicitly concerning the method of hisab and ru'yat. It is important to explore to avoid a one-sided truth claim and judgement towards other groups. An interpretative approach is an approach used by Clifford Geertz in the researches in Anthropology, it examines religion from the insider's point of view and attempts to look for the meaning behind their behaviour. The opposite of the aforementioned approach is explanatory approach, which examines religion from the outsider's perspective (Fitriani 2015).

Religion and culture are two essential aspects that are interrelated and influence each other in the structure of society. When religious teaching penetrates a cultural community, there will be a conflict between religious and cultural interests. On the other hand, the interaction of Islam and local culture is an attempt to discern the dynamic relationship between Islam and various values and concepts of life that are nurtured and inherited as the guidelines of life (Rozi 2012). The main mission of Prophet Muhammad as a messenger of God is to construct a civilised social order that is reflected in his word, 'Indeed, I have been sent to complete the best of character' (Al-Mubarakfuri 2001:470).

Islamic religious expressions are institutionalised in various religious practices both in the form of religious thoughts such as madhhab or symbolic attributes. The diversity of symbols in Islam is a repertoire that enriches the meaning of Islam 
and proof of the adaptability of Islamic doctrine to face the flow of social changes. Although Islam's religious doctrine is oneness, its religious expression is very diverse and is not monolithic (Abdurrahman 2005:11). Symbols are the characteristic of religion because they are established from belief, ritual and religious ethics. Symbols are also interpreted as signs that are cultic in various forms according to the culture and beliefs of each religion.

As religious phenomena, symbols are manifested in various forms of adoration and worship performed individually and communally (Calo 2012). The factors influencing religious symbols to correlate with religious experience are because of the fact that symbols of religion are often used to assist psychological therapy. Human as homo symbolicus is constructed by two interrelated dimensions, namely spiritual and psychological dimensions. The spiritual dimension is oriented towards religion meanwhile, the psychological dimension is oriented towards freedom. They are manifested in various forms of symbols (Wahab 2011).

In the literature of symbol orientation, four systems of symbols are arranged coherently, namely cognitive symbolisation, moral symbolisation, expressivesymbolisation and constitutive symbolisation. Cognitive symbols have coherence with science, moral symbols are related to various normative provisions, expressive symbols are related to works of art and constitutive symbols are related to belief and worship, which are the main behaviours of religion.

The differences amongst Islamic organisations vis-à-vis the government could become more complex when political and business interests also play a role. Competition would lead to a contest over Islamic authority, in a plural society such as Indonesia (Hosen 2012).

The above-mentioned four systems have a function to figurate four demands of religious life in their various forms. The four demands are adaptation, goal attainment, integration and latent pattern maintenance. All these demands are a series of needs related to the systems of religious life. When an identity is constructed, it cannot be separated from interests. Hence, identity can be a source of uncertainty and even a conflict (Hamdi 2017).

As a norm, religion is one of the aspects of social identity. There are several functions of religious identity. Firstly, religious identity is a spiritual need. It is also the need to be included in the community. Secondly, religious identity and expression serve to reduce tension and help individuals to overcome social isolation. Thirdly, religious identity is used to maintain the distinctiveness of a religious community.

\section{Methodology}

This research is field research that originates from the results of interviews and observations of opinions and arguments of the management of NU and Muhammadiyyah regarding the initial determination of Ramadan and Shawwal and also the statements of mass media in Indonesia. The approach used in this research is qualitative research by collecting data, sorting out the main and supporting data, then displaying the data and analysing the data (Miles 1992).

Primary data are derived from the opinion of NU and Muhammadiyah associated with the Huberman theory regarding the existence of the use of social symbols, in this case the hisab and ru'yat methods in determining the beginning of the month. The data are described and commented on so that it becomes the result of objective research that is free from distorted interpretations.

\section{Results}

\section{Ru'yat and Hisab: Religious identity contestation in public sphere}

In Indonesia, determining the beginning of essential months of the Islamic lunar calendar has been a similar problem for Muslims every year. Especially in determining the beginning of three months with major Islamic events; firstly, Ramadan in which Muslims expect the beginning of fasting; secondly, Shawwal to determine the end of the fasting and to celebrate the big day of Eid al-Fitr and thirdly, Dzulhijjah to celebrate the second biggest day of Muslims, Eid al-Adha.

The differences in determining the beginning of Ramadan, Shawwal and Dzulhijjah are caused by the different methods used by the organisations, the methods are ru'yat (sighting a new crescent moon), hisab (astronomic calculation) and ru'yat supported by hisab and hisab supported by ru'yat. These differences do not happen only in Indonesia, but also occur in several neighbouring countries such as Malaysia, Singapore and Brunei Darussalam with the following details: ru'yat method is used by NU and Brunei Darussalam; hisab method is used by Muhammadiyah, PERSIS and Singapore. The combination of ru'yat and hisab method is used by Malaysia, the Indonesian Council of Ulema and the Ministry of Religion of the Republic of Indonesia (Thohari 2012).

Hisab is usually presented by Muhammadiyah and other Islamic organisations with the same viewpoints, whilst ru'yat is presented by the government and other Islamic organisations with the same viewpoints through isbat meeting coordinated by the Ministry of Religious Affairs. The differences in determining the beginning and end of Ramadan portray the existence of the mainstream cluster, namely the government and NU and the anti-mainstream cluster, namely Muhammadiyah.

Suhanah's research in the city of Semarang, Central Java, Indonesia showed that the difference in determining the beginning of fasting and Eid al-Fitr arouse a lot of anxiety amongst Muslims. For example, Cipto and his son had different opinion in following the mainstream of the beginning and end of Ramadan fasting (Suhanah 2012). His 
son celebrated Eid al-Fitr earlier than him because the son followed the decision made by Muhammadiyah, whilst his parents waited for the decision made by the government and NU. The phenomenon of the asynchronous decision, especially between NU and Muhammadiyah, stimulated psychological unrest amongst people, it resulted in the weakening family relationship.

Nahdlatul Ulama applies ru'yat in determining the beginning and end of Ramadan as stated in the decision of the NU XXVII Congress in Situbondo 1984, the Alim Ulema National Conference in Cilacap 1987 and the NU Lajnah Falakiyah Working Meeting in Pelabuhan Ratu (1992). The decision emphasised that NU based on legal maxim is ru'yat al-hiläl bi al-fi'li or istikmāl (sighting a new crescent moon or completing the 30 days for sya'ban). Hisab is only a tool in carrying out ru'yat. The determination of the beginning of month is applicable for all Indonesian Muslims and carried out by the government (ithbāt al-häkim). Concerning the ru'yat by enforcement line, NU applies this principle of enforcement line.

The implementation of sighting a new crescent moon on the night of the 29th or the 30th of the months is based on several hadiths related to ru'yat and the ulema's opinions of all madhhabs except Hambali. Some of the reference books used by NU are those written by Imam Nawawi entitled al-Majmu syarh al-Muhazzab, written by Ibn Hajar entitled Hawasiyy Tuhfah Muhtaj and written by Syekh Ramli entitled Nihayah al-Muhtaj. This decision was made based on Islamic law reasons, which were considered valid to be used as guidelines for worship and could be accounted (Seff 2014:79).

The head of NU, Said Aqil Siradj states that the determination of the first day of Ramadan and the first day of Shawwal should be in accordance with hadith from Muhammad on using the sighting a new crescent moon (rukyatul hilal), Prophet Muhammad said:

[F]ast on sighting it (the crescent) and break (fast) on sighting it (the crescent of Shawwal), but if the sky is cloudy for you, then complete the number (of thirty).

That is the normative argument presented by Said Aqil Siradj by quoting proposition about sighting a new crescent moon from hadith. According to Said Aqil, the government and most of the socio-religious organisations in Indonesia such as NU, PERSIS, Matlaul Anwar, al-Wasliyah and Indonesian Islamic Students (IIPPs) use the aforementioned method to determine the beginning of Ramadan month (ICMI Media 2015).

On the contrary, Haedar Nasir the head of Muhammadiyah emphasises that the organisation determines the beginning of Ramadan based on the result of astronomic calculation (hisab hakiki wujudul hilal) as seen in the guidance of Tarjih and Tajdid of Muhammadiyah (Republika 2018). The use of astronomic calculation method is outlined in the decision of Muhammadiyah Special Congress in Pekalongan back in 1972. Formally, the astronomical calculation method is written in the decision compilation of the Muhammadiyah's assemblies of Tarjih and Tajdid. The main concept used by Muhammadiyah as the guideline is hisab wujūd al-hilāl and hisab milād al-hilāl. Hence, Muhammadiyah uses hisab hakiki wujudul hilal to determine the beginning of Islamic lunar months. Hisab in the months are considered after meeting the following criteria: ijtima' (conjunction) has occured, the conjunction happens prior to sunset and when the sun sets, part/s of the crescent has occurred above on the horizon (the crescent moon has come into being). The three criteria have to be fulfilled cumulatively, all at once. If it lacks one of the criteria then the new month has not yet begun (PP Muhammadiyah Majelis Tarjih dan Tajdid 2009).

The method of hisab is defined as astronomical calculations to determine the position of the moon (Marwadi 2018). Therefore, this method allows the first day of Ramadan to be set on a date of the Gregorian calendar long before the month arrives. On the other hand, ru'yat is conducted by observing the emergence of the crescent moon after the conjunction. $R u^{\prime} y a t$ can be carried out with a naked eye or through optical lenses such as telescopes. The ideal time to conduct ru'yat is before and right at the sunset. Hilal is only visible after sunset, because the light intensity of the hilal is much fainter than the sun. When the hilal is visible, the new month of the Islamic calendar is started, and if not visible, the beginning of the new month is start to the next day.

Historically, public sphere emerged for the first time in the 17th century in Europe, at the same time when capitalism was developing. During the era of proto-capitalism, a new class in society emerged, named bourgeois class. In the beginning, they just conducted typical trading activities but as time flew they started to develop capitalism. As a result of this background, the emerging public spheres at that time were closely related to the bourgeois classes, dominated by traders and professionals.

Bourgeois stated that public spheres were spaces privately owned by individuals who gathered as a public entity. The state is encouraged to be involved in private-but-publiclyrelevant issues (Prasetyo 2012a). In the network of public spheres, social gatherings are the most important elements for civil society. It is because of the fact that civil society can be an important background of the growth of the democratic culture (Prasetyo 2012a). The distinction between public (state) and private is a construction that becomes the foundation of public sphere concept.

According to Habermas as quoted by Qodir, contestations amongst social groups have always been a part of public sphere. Every group attempts to influence society to gain credit and thus win the discord. Therefore, there is no public sphere without contestation, including on religious affairs (Qodir 2015).

In any community, identity is an inseparable need for people regardless of the real meaning of the identity they choose or use (Ittihadiyah 2008). One of the aspects of identity that most people show to gain recognition in society is religion 
(Muchtar Ghazali \& Hasanah 2020). Religious identity is used to uphold the special characteristic of a certain religious group and to affirm its distinctive characteristic amongst other groups.

Symbols or signs can be defined as concepts perceived by people as a special characteristic of something else containing qualities of logical analysis, associations in thoughts or fact (Muchtar Ghazali \& Hasanah 2020). A symbol stimulates a message that encourages idea or action (Hasbullah 2011). Religion is a social representation therefore social phenomena are often addressed in a religious perspective (Payne 1996).

Religious identity is closely related to the devotion of a believer. Glork and Stark identify five main dimensions of religion: Firstly, the dimension of belief, a devoted believer is expected or demanded to believe, this belief is concerned with means of beliefs that give an 'existential premise' to elaborate the relationships amongst God, nature and human beings. Secondly, the dimension of practice covering religious practices such as prayers and other activities suggested in the guidance of the religion, each religion has rituals, prayers and worships to be carried out by the believers, although the emphasis on those activities varies from one another. Thirdly, the intellectual dimension that emphasises the knowledge of the religion and its guidelines including the basics of the faith. Fourthly, the cognitive dimension. This dimension covers feeling, experience and emotion emerging in and from the environment. Fifthly, the consequential dimension. It is a dimension that involves secular influences towards the belief, practice, experience and knowledge of a believer (Rozi 2012).

According to Casanova, there are three main conditions for religious influence to appear in public. Firstly, doctrine or religious tradition as a part of communal or public identity. Secondly, the existence of revitalisation and reformation of classic tradition, which is still intact and the involvement of religion in public spheres. Thirdly, the contemporary global context of action demands that religion takes a role in public spheres (Effendi 2009:78).

On Ahmad Izzudin's viewpoint, ru'yat hilal as a method to determine the beginning and the end of Ramdhan is merely an instrument, what really matters is the worship, which is the fasting. However, although the ru'yat is an instrumental dimension, the post-determination implication to society is considered as a public dimension. To bridge the difference between hisab and ru'yat, the government invited representatives of social groups to sit in one assembly and make decisions through jurisdictional meetings. The context of the public sphere here is an area in which national and communal interests coexist (Rauchfleisch 2017). Discussion on the public sphere is directly correlated with the concept of civil society (Calhoun 1993:267-280). According to Izzudin, public generally relies on the decision drawn by the government (Izzudin 2018).
Fathurrohman, a Muhammadiyah astronomer, stated the choice of ru'yat or hisab methods is in the area of ijtihadiyah, which is open to the occurrence of legal differences, whilst the obligation to perform the worship of fasting is absolute. The hadith on the command to perform the $r u^{\prime}$ yat al-hilal in determining the beginning of Ramadan also gives space to hisab method, which allows the possibility to complete sya'ban month to become 30 days (Fathurrohman 2018).

According to Azhari, Muhammadiyah relates revelation with human civilisation. Therefore, in establishing the beginning of Ramadan and Shawwal, Muhammadiyah does not solely use ru'yat but hisab methods. For Muhammadiyah, which develops rational and scientific reasoning, $r u^{\prime}$ yat is not merely understood literally and partially, but is negotiated with related verses, such as Q.S. al-Baqarah verse 185 and Q.S. Yunus verse 5, so that the method developed by Muhammadiyah in establishing the beginning of the Qamariyyah months is not only productive but also elastic (Azhari 2006).

The statements by the two astronomers of NU and Muhammadiyah show similarity on the perspective that $r u^{\prime} y a h$ and hisab are no others but means to reach an objective, the worship which is the subject of the two methods and a part of Islamic dogma that must not be argued upon is the fasting itself.

According to Izzudin, the meaning of ru'yat is textually understood and based on empirical facts as practiced by the Prophet, namely physical observation by seeing the crescent moon. Whilst Fathurohman interprets the hadits by their symbolic meaning rather than literal that gives space for hisab. The choice for hisab is based on a rational argument that hisab guarantees certainty and is measured by the scientific approach.

What happened in the determination of 1st Ramadan in the year of 2014 is an example. Muhammadiyah decided the beginning of fasting on June 28 based on hisab hakiki with the criteria of the appearance of the crescent. Whilst NU set 1st Ramadan on the following day, June 29, by considering the position of hilal that was 0.085 degrees. Sya'ban month should be completed by 30 days because of the position of the hilal that could not be seen (Voa Islam 2014).

The difference in determining the beginning and end of Ramadan has been placing the two largest religious organisations in Indonesia, Muhammadiyah and NU, in a suspenseful confronting relation performed in the public sphere, dragging communities to the whirl of 'conflict'. The conflict contributes to the transformation of fasting from the private domain into the public domain. What makes fasting to have a strong public domain is the euphoria of Muslims in celebrating this holy month and the subsequent celebration day of Eid al-Fitr as a communal tradition, which has tremendous systemic effects on social and 
economic aspects considering Muslims as the majority population in Indonesia.

The contestation of religious symbols in the public sphere is the competition of images of religious organisations to strengthen their position and legitimacy in society. Religious terminology is used as a symbol to construct internal, emotional and ideological relationships amongst the followers of a certain religious organisation. For Muhammadiyah, taking a different position from the mainstream groups (the ru'yat group) in determining the beginning and end of Ramadan puts them as a large religious organisation in an equal position to its competitors. In this matter, symbolic contestation is a media for self-identity affirmation (Ollero n.d.).

The public implicitly admitted the contestation of Muhammadiyah and NU through religious symbols of $r u^{\prime} y a t$ and hisab in determining the beginning of fasting and the celebration of Eid al-Fitr. Suhanah's research in the city of Semarang, Central Java presented an impact caused by the conflict in the form of psychological pressure experienced by the community whilst waiting for the decision to be made by the government (Puslitbang \& Keagamaan 2004). These research data show that the reality of difference causes the emergence of significant social impacts, namely the threat of social disharmony.

\section{The contestation between mainstream group and anti-mainstream group}

Every year, Indonesian Muslims expect the celebration of Ramadan and Eid al-Fitr to be determined on the same day for all social groups, they long for the togetherness as proof of solidarity amongst them and socio-religious organisations. They feel relieved if the two largest Muslim organisations in Indonesia, namely Muhammadiyah and NU, come to the same decision in starting the Ramadan fasting and celebrating Eid al-Fitr (Thohari 2011). However, the symbolic contestation between the two has been going on for a long time, efforts have been carrried out frequently through dialogues to formulate methodological compromises to find solutions and common ground.

The statement of the President of the Republic of Indonesia, Joko Widodo, during his speech at Nurul Iman Mosque in Padang depicted the reality of the contestation of religious identity in determining the beginning of the holy months through hisab and ru'yat. The Isbat meeting held by the Ministry of Religious Affair in 2016 drew a conclusion that the Eid Al-Fitr of 1437 Hijriyya would be celebrated on the same day, which was Wednesday. The President stated, 'I hope in the upcoming years, NU and Muhammadiyah would continue to be unified in determining the other crucial Islamic holidays' (Republika 2016).

The chairman of the Indonesian Council of Ulema, Ma'ruf Amin comments regarding the unification as stating to be grateful that both organisations begin the fasting month of Ramadan of 1437 Hijriyya on the same day, Monday, 06 June 2016 (Indonesia 2016).
Both statements clearly indicated the existence of contestation between the two organisations. The president emphasised that the harmony and internal Islamic brotherhood would be well maintained if the two major Islamic organisations in Indonesia are on the same boat in determining the beginning and the end of Ramadan.

The existence of religious symbol contestation between socioreligious organisations in Indonesia has turned fasting and Eid Al-Fitr celebration as an arena for demonstrating the organisations' existence concealed in religious reasoning frameworks. The determination of the beginning and the end of fasting month has shifted the paradigm of fasting and Eid Al-Fitr celebration to have both private and public dimensions.

Religious communities have experiences in comprehending and carrying out the values with devotion. The spiritual experiences are often correlated with religious symbols distinguishing a certain religious community from the other ones (Stolle et al. 2016). Religious symbols are essential to find the meaning, thought and spiritual experience of a religion (Erel-Koselleck 2004). Symbols are one of religious expressions to represent an idea and manifest thought in religious rituals (Ofuafo 2013). Religious symbols are not religion, but interpretations of religious doctrines, which are used as certain symbols or attributes for religious organisations and become part of organisational behaviour and culture.

The determination of the beginning and the end of Ramadan has transformed into an arena of symbolic contestation for the religious interpretation authorities in the public sphere. The aim is to show the existence of the beliefs embraced by the authorities through the symbols of either ru'yat or hisab. As a method, both ru'yat and hisab are principally neutral. However, as each is chosen by two major organisations, it has transformed into attributes of the organisations to distinguish their identity.

Religion has the potential to develop an identity based on transcendental truth. Even so, religion does not only provide transcendental worldview and moral beliefs but also encourage believers to practice the value in their social life (Ebstyne King 2003). The different systems in value, culture and beliefs tend to classify people in competitive group boundaries rather than cooperative relationship. The tendency to dominate social relations will eventually lead to traditional and primitive laws in which the stronger groups have control over the weak groups and have the power to formulate laws (Francis 2006:7-8).

Conflict is closely related to integration. The higher the degree of conflict in a group, the smaller the degree of integration. Theoretically, in-group solidarity and out-group conflict have cause-and-effect relations (Susanto 1985:103). Religious identity is one of the social categories based on ideological ties as a means to emphasise the in-group and 
out-group views of their members. Contestation of Islamic groups on the basis of ideology and religious beliefs in the form of religious symbols in public space is very real in the Indonesian Muslim community (Takdir 2020).

Referring to the theories of public sphere, Habermas points out that the public sphere is an autonomous space in a country for it does not exist from administrative power and instead from civil society. Public sphere is a battle arena for discourse and argumentation to take place. It is also a locus to unify conflicts and claims of competition and the differences that cannot be settled (Menoh 2015:87). Public sphere also holds an important role in constructing politic democratisation and a mean of communication, discussion and argumentation (Hardiman 2014a:11).

Regarding the positioning of NU amidst public discourse about the determination of the beginning and the end of Ramadan, the Head of NU, Said Aqil Siradj points out that the determination of 1st of Ramadan and 1st of Syawal has to be inclined with a hadith regarding ru'yatul hilal that states, 'fast on sighting it and break on sighting it, but if the sky is cloudy for you, then complete the number (become thirty)'. According to Siradj, determining the beginning and the end of Ramadan by using hisab only is not sufficient (ICMI Media 2015), NU is in accordance with the method chosen by the Indonesian government. Therefore, in Indonesia, the dissent is generally divided into two groups: the government and NU as a mainstream group versus Muhammadiyah and those who are in the same lane as them in an anti-mainstream group.

For instance, in 2016, the Head of Muhammadiyah determined that the beginning of Ramadan was on Monday, 06 June 2016 after conducting hisab without observing the hilal. Other groups, mainly NU, stated that to determine the beginning of the month, a hilal direct observation is a must. The government through the Minister of Religious Affairs Lukman Hakim stated that the decision of the government regarding the first day of Ramadan employed two methods used by both NU and Muhammadiyah, namely hisab and $r u^{\prime}$ yat. According to the Minister, there was no difference in the result of two methods. Hence, Ramadan of 1437 Hijriyya began on Monday, 06 June 2016 (Indonesia 2016).

The symbolic contestation between Muhammadiyah and NU was implied by Ma'ruf Amin upon finding out that there was no difference in the beginning of Ramadan between Muhammadiyah and NU in 2016 by stating that he was grateful about it. President Joko Widodo agreed by saying 'Alhamdulillah, Indonesian Muslims begin the fasting month and Eid Al-Fitr at the same time and hopefully this will continue from here on'. The president hoped that in the upcoming years, NU and Muhammadiyah will continue to be united in determining other Islamic holidays (Republika 2016). According to Habermas, personal norms and traditional social behaviour society usually comes from an incontrovertible religious belief system. These norms are usually supported and reinforced by an appointed sacred authority (Habermas 2015).

The contestation of religious symbols between Muhammadiyah and NU is obvious considering the statement of Abdul Mu'ti, the General Secretary of Muhammadiyah who estimated Ramadan of 2017 began on 27 May 2017. The statement was based on the position of hilal which is 8 degrees meaning that those who conducted $r u^{\prime}$ yat method will definitely see the hilal. He stated, if the 8 -degrees hilal is seen, then the government does not need to do Isbat meeting. The Minister of Religious Affairs just needed to ask reports from each regional representative and the mass organisation' (Republika 2016).

The statement of Abdul Mu'ti claiming that the Isbat meeting was not necessary implied the prominence of hisab method and disclaimed ru'yat method for reasons such as theoretical certainty based on scientific argumentation that the hilal must be sighted. On the other hand, the believers of ru'yatul hilal claimed that ru'yat is a part of the religious order that has a dimension of worship, which must be conducted in any situation or condition. The articulation of religious understanding by various groups of religious organisations in Indonesia creates various variants, all of which struggle to control the public space to strengthen their dominance and existence in society (Qodir 2011).

The position of the government in determining the beginning and the end of Ramadan is represented by the statement of Faturohman, a board of Muhammadiyah. He stated that the policy in determining the hilal for ru'yat, for instance by benchmarking ru'yat, cannot be used as standard because standardisation is based on experiences that could be different. In such condition, the role of government is not necessary to meddle in managing religious aspect that is ijtihadiyah. In practice, the decision of the government regarding the determination of the beginning and the end of Ramadan in Isbat meeting seems to have a bias towards certain groups and it is the trigger for the emergence of discords and group split in Muslims. The government belongs to all components of the nation; hence it should be the one who unifies and not the one who takes side with a certain group only (Fathurrohman 2018).

The statement of Fathurohman that perceived the government's bias towards ru'yat madhhab or a certain religious organisation implies the doubts on the result of Isbat meeting. It also strengthens the reality of contestation between religious symbols in the public sphere. Because of the reform and the change in direction of national politics, the positioning of the political mass organisation has also been changed. Therefore, politics affects the emergence of such contestation.

Ever since the reform era, the position of NU in the national political constellation is more beneficial. They also hold the authority to form political and religious policies at the same time. The positions of the Indonesian Minister of 
Religious Affairs and the Head of Indonesia Ulama Council are always carried out by the members of NU. This political position is the main factor in strengthening religious identity in the public sphere. The idea of moderate Islam and the development of Islam with national insight lead NU to adapt and do a synergy with political powers from the nationalist as the current political power in Indonesia.

Hisab and ru'yat are not only methods of determining the beginning and end of Ramadan but they also symbolise the contestation of the religious organisations $\mathrm{NU}$ and Muhammadiyah in the public sphere. This research is limited to analysing the behaviour of the NU and Muhammadiyah religious organisations in the public sphere, which make ru'yat and hisab methods as a symbol of contestation in affirming their existence in the public sphere. In line with that, this article suggests the need for a study that examines the public's response to the use of the ru'yat and hisab methods as a symbol of contestation in public sphere.

\section{Conclusion}

In Indonesia, the methods to determine the beginning and the end of Ramadan by applying ru'yat and hisab, which are both initially neutral, are biased because they are used as attributes of certain religious organisations. The determination process has been transformed into a contestation arena between religious symbols to affirm the existence of their religious interpretations and beliefs. The contestation of religious symbols in the public sphere is a competition of images of the religious organisations in upholding their position and social legitimacy. Religious terminologies are employed as symbols to facilitate the construction of internal, emotional and ideological relations amongst the members of the socio-religious organisations. In this context, the contestation is a media to declare selfidentity. Fasting and other Islamic holidays become the arena to demonstrate the existence of the organisations through religious reasoning.

The difference in determining the beginning and the end of Ramadan in Indonesia has been placing two major socioreligious organisations in Indonesia, Muhammadiyah and NU in psychologically tense interactions in public sphere dragging their members in the 'conflict whirl'. This implies the transformation of fasting from supposedly privateindividual into public-dimension worship. The strong public dimension of Ramadan in Indonesia is because of the traditional characteristic of Eid Al-Fitr as a communal celebration, which has systemic impacts on the social and economic lives of the community, given that Muslim is the majority of Indonesian population. The government and Indonesian Council of Ulema (MUI) initiated to bring together two mass organisations and compromise the methods of hisab and ru'yat through the work of methodological unification with the spirit of togetherness on the basis of the common good and minimising tension.

\section{Limitations of this study}

This study is limited to determining the beginning of the Islamic calendar by two methods of hisab and ru'yat. For further research related to determine the beginning of the Islamic calendar in the Muslim world, researchers need to combine the two methods of hisab and ru'yat.

\section{Acknowledgements Competing interests}

The authors declare that they have no financial or personal relationships that may have inappropriately influenced them in writing this research article.

\section{Authors' contributions}

R.R. presented the idea and developed the theory and data. M.F.Z. contributed to the writing and editing of the manuscript.

\section{Ethical considerations}

This article followed all ethical standards for research without direct contact with human or animal subjects.

\section{Funding information}

This research was funded by Institut Agama Islam Negeri Purwokerto.

\section{Data availability}

Data sharing is not applicable to this article as no new data were created or analysed in this study.

\section{Disclaimer}

The views and opinions expressed in this article are those of the authors and do not necessarily reflect the official policy or position of any affiliated agency of the authors.

\section{References}

Abdurrahman, M., 2005, Islam yang memihak, Lkis Pelangi Aksara, Yogyakarta.

Al-Mubarakfuri, M.A. ibn A., 2001, Tuhfah al-Ahwadzi bi Syarh Jami'at-Tirmidzi, Dar al-Hadis, Beirut.

Azhari, S., 2006, 'Karakteristik Hubungan Muhammadiyah dan NU dalam menggunakan Hisab dan Ru'yat', Al-Jami'ah: Journal of Islamic Studiesah 44(2), 453-486. https://doi.org/10.14421/ajis.2006.442.453-485

Calhoun, C., 1993, Civil society and the public space: The Oxford handbook of civil society, Oxford University Press, Oxford.

Calo, Z.R., 2012, 'Higher law secularism: Religious symbols, contested secularisms, and the limits of the establishment clause', Chicago Kent Law Review 87, 811.

Capps, W.H., 1995, Religion studies, Fortress Press, Minneapolis, MN.

Coşgel, M.M.L.M., 2004, 'Religious identity and consumption', Review of Social Economy 62(3), 339-350. https://doi.org/10.1080/0034676042000253945

Djamaluddin, T., 2011, Astronomi Memberi Solusi Penyatuan Ummat, LAPAN, Jakarta.

Ebstyne King, P., 2003, 'Religion and identity: The role of ideological, social, and spiritual contexts', Applied Developmental Science 7(3), 197-204. https://doi. org/10.1207/S1532480XADS0703_11

Effendi, B., 2009, Agama Publik dan Privat, UIN Syarif Hidayatullah, Jakarta.

Erel-Koselleck, E.S., 2004, 'The rule power of symbols in the identity formation of community members', Masters thesis, Middle East Technical University. 
Fathurrohman, O., 2018, Interview: Pengurus Majelis Tarjih Pengurus Pusat Muhammadiyah.

Fitriani, M.I., 2015, 'Kontestasi Konsep Religious dan Ritualitas Islam Pribumi Versus Islam Salafi di Sasak Lombok', Teosofi: Jurnal Tasawuf Dan Pemikiran Islam 5(12), 513-531. https://doi.org/10.15642/teosofi.2015.5.2.513-531

Francis, D., 2006, Teori Dasar Transformasi Konflik Sosial, Penerbit Quills, Yogyakarta. Habermas, J., 2015, Between facts and norms: Contributions to a discourse theory of law and democracy, John Wiley \& Sons.

Hamdi, A.Z., 2017, Berebut Identitas Nadhiyyin, NU Online.

Hardiman, B.F., 2014a, Komersialisasi Ruang Publik Menurut Hannah Arendk dan Jurgen Habermas: Dalam Ruang Publik Melacak Partisipasi Demokratis dari Polis sampai Cyberspace, Kanisius, Yogyakarta.

Hardiman, F.B., 2014b, Komersialisasi Ruang Public menurut Hannah Arendt and Jurgen Habermas, Kanisius, Yogyakarta.

Harris, M., 1968, The rise of antropological theory, Crowell, New York, NY.

Hasbullah, 2011, 'Agama dan Etnisitas di Pentas Politik Lokal (Tinjauan Terhadap Penggunaan Simbol Agama dan Etnis dalam Pilkada)', Ushuluddin 17(2), 170-182. http://doi.org/10.24014/jush.v17i2.690

Hosen, N., 2012, 'Hilal and Halal: How to manage Islamic pluralism in Indonesia?', Asian Journal of Comparative Law 7(1), 1-18. https://doi.org/10.1017/ S2194607800000661

ICMI Media, 2015, PBNU: Penetapan Awal Ramadhan dan Syawwal Harusnya Ikut Hadis Nabi, ICMI Press, Jakarta.

Indonesia, B., 2016, NU-Muhammadiyah Sepakat Awal Ramadhan, BBC Indonesia.

Ittihadiyah, H., 2008, 'Merunut Identitas Islam Indonesia (Kajian Historiografi menurut Ulama Kontemporer Yogyakarta Perspektif Muhammadiyah, NU, HTI dan MMI)', Jurnal Penelitian Agama 17(3).

Izzudin, A., 2018, Interview: Koordinator Penelitian dan Pengembangan Lembaga Falakiyah Pengurus Besar Nahdhatul Ulama.

Jubba, H., Abdullah, I., Pabbajah, M., Iribaram, S., Prasojo, Z.H. \& Qodir, Z., 2020, 'The display of religious symbols in public space: The contestation of muslim and christian identities in jayapura, Papua', Humanities and Social Sciences Reviews christian identities in jayapura, Papua', Humanities and
$8(1), 642-650$. https://doi.org/10.18510/hssr.2020.8177

Kim, R.Y., 2011, 'Religion and ethnicity: Theoretical connections', Religions 2(3), 312-329. https://doi.org/10.3390/rel2030312

Malinowski, B., 1922, Agronout of Western Pacific, Routlege, London.

Marwadi, M., 2018, 'Interkoneksi Fikih Hisab Rukyat dan Ilmu Geodesi', Al-Manahij: Jurnal Kajian Hukum Islam 12(2), 217-232. https://doi.org/10.24090/mnh v12i2.1768

Menoh, G.A.B., 2015, Agama dalam Ruang Publik: Hubungan antara Agama dan Negara dalam Masyarakat Postsekuler Menurut Jurgen Habermas, Kanisius, Yogyakarta.

Miles, M.B.D.A., 1992, 'Michael Huberman', in Qualitative data analysis: An expanded sourcebook, SAGE, s.l.

Muchtar Ghazali, A. \& Hasanah, A., 2020, 'Understanding the religious tolerance in Indonesia: The Islamic theological perspectives', Humanities \& Social Sciences Reviews 8(1), 699-706. https://doi.org/10.18510/hssr.2020.8184

Ofuafo, P.U., 2013, 'Art symbols as means of communicating religious concepts in Urhobo traditional society', Uluslararas/ Sosyal Arast/rmalar Dergisi/The Journal of International Social Research 6(27), 392-397.

Ollero, A., n.d., Religious symbols in public spaces: Ethical and legal arguments.
Oppong, S.H., 2013, 'Religion and identity', American International Journal of Contemporary Research 3(6), 10-16. https://doi.org/10.30845/aijcr

Payne, G., 1996, 'Malcolm B. Hamilton. The sociology of religion', Sociology-London 30(4), 813-814. https://doi.org/10.1177/0038038596030004012

Peek, L., Adler, P., Adler, P., Butler, D., Jacobs, J., Fran Myers, M. et al., 2005, 'Becoming Muslim: The development of a religious identity', Sociology of Religion 663, 215-242. https://doi.org/10.2307/4153097

PP Muhammadiyah Majelis Tarjih dan Tajdid, 2009, Pedoman Hisab Muhammadiyah, Jakarta.

Prasetyo, A.G., 2012a, 'Menuju Demokrasi Rasional: Melacak Pemikiran Jürgen Habermas tentang Ruang Publik', Jurnal IImu Sosial Dan IImu Politik 16(2), 169-185. https://doi.org/10.22146/jsp.10901

Prasetyo, A.G., 2012b, 'Menuju Demokrasi Rasional: Melacak Pemikiran Jurgen Hubermas Tentang Ruang Publik', Politics and Social Sciences (JSP) 16(2), 169-185. hubermas Tentang Ruang Publik, Politic
https:/doi.org/10.22146/jsp.10901

Puslitbang, P. \& Keagamaan, K., 2004, Dampak Sosial Perbedaan Pendapat dalam Penentuan Awal Ramadhan dan 1 Syawal terhadap Umat Islam di Kota Semarang, pp. 156-168, Jakarta.

Qodir, Z., 2011, 'Public sphere contestation: Configuration of political Islam in contemporary Indonesia', Indonesian Journal of Islam and Muslim Societies 1(1) 123-149. https://doi.org/10.18326/ijims.v1i1.123-149

Qodir, Z., 2015, 'Kontestasi Penyiaran Agama di Ruang Publik: Relasi Kristen dan Islam di Kota Jayapura', HARMONI: Multicultural and Multireligious 14(1), 38-52.

Rauchfleisch, A., 2017, 'The public sphere as an essentially contested concept: A cocitation analysis of the last 20 years of public sphere research', Communication and the Public 2(1), 3-18. https://doi.org/10.1177/2057047317691054

Republika, 2016, Umat Islam Indonesia Kompak Rayakan Lebaran, Ini Komentar Jokowi, Republika, Jakarta.

Republika, 2018, Muhammadiyah Umumkan Awal Ramadhan-Syawwal-Dzulhijah 1438 H, Republika, Jakarta.

Rozi, S., 2012, Konstruksi identitas islam perbatasan sebuah sintesis terhadap identitas tradisional dan identitas modernis dalam paham keagamaan di daerah rao sumatera barat, Jakarta.

Seff, S.M., 2014, Metode penetapan hari raya Idul Fitri di Indonesia dalam tinjauan hukum Islam, IAIN Antasari Press, Banjarmasin

Stolle, D., Harell, A., Soroka, S. \& Behnke, J., 2016, 'Religious symbols, multiculturalism and policy attitudes', Canadian Journal of Political Science 49(2), 335-358. https:// doi.org/10.1017/S0008423916000561

Suhanah, S., 2012, 'Dampak Sosial Perbedaan Pendapat dalam Penentuan Awal Ramadhan dan 1 Syawal terhadap Umat Islam di Kota Semarang', Harmoni 11(2), 156-168.

Susanto, A.S., 1985, Pengantar sosiologi dan perubahan sosial, PT. Bina Cipta.

Takdir, M., 2020, 'Contestation and the roles of Islam in the public sphere: A sociological analysis of religious secularization in Indonesia and the West', Afkaruna: Indonesian Interdisciplinary Journal of Islamic Studies 16(2), 154-174.

Thohari, F., 2011, 'Fatwa Mui Tentang Penentuan Awal Ramadhan, Syawal, Dan Dzû Al-Hijjah (Upaya Rekonstruksi Metodologis)', Al-'Adalah 10(2), 179-184.

Thohari, F., 2012, Fatwa MUI Tentang Awal Ramadhan, Syawwal dan Dzulhijjah (Upaya Rekonstruksi Metodologis), Litbang Kemenag RI, Jakarta.

Voa Islam, 2014, Awal Puasa 2014: Muhammadiyah dan NU Beda Tetapkan 1 Ramadan, Voa Islam, Jakarta.

Wahab, M.H.A., 2011, 'Simbol-Simbol Agama', Subtantia 12(1), 79-84. http://doi. org/10.22373/substantia.v13i1.4813 